
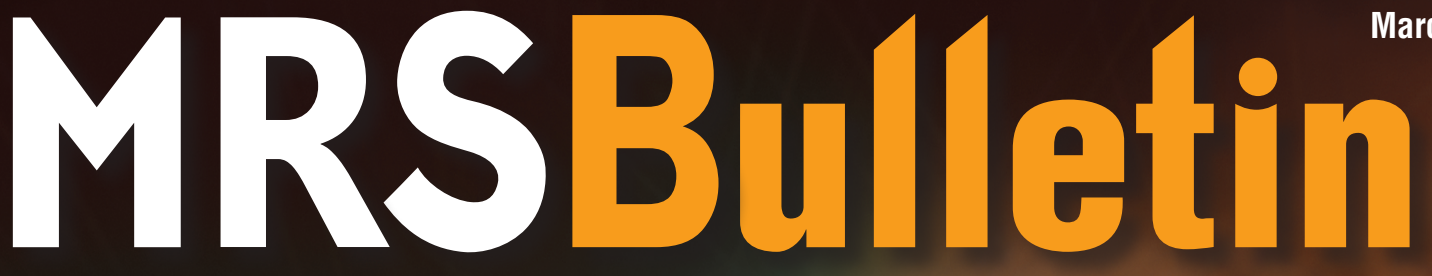

March 2012 Vol. 37 No. 3

www.mrs.org/bulletin

MRSS MATERIALS RESEARCH SOCIETY

\title{
Materials for stretchable electronics
}

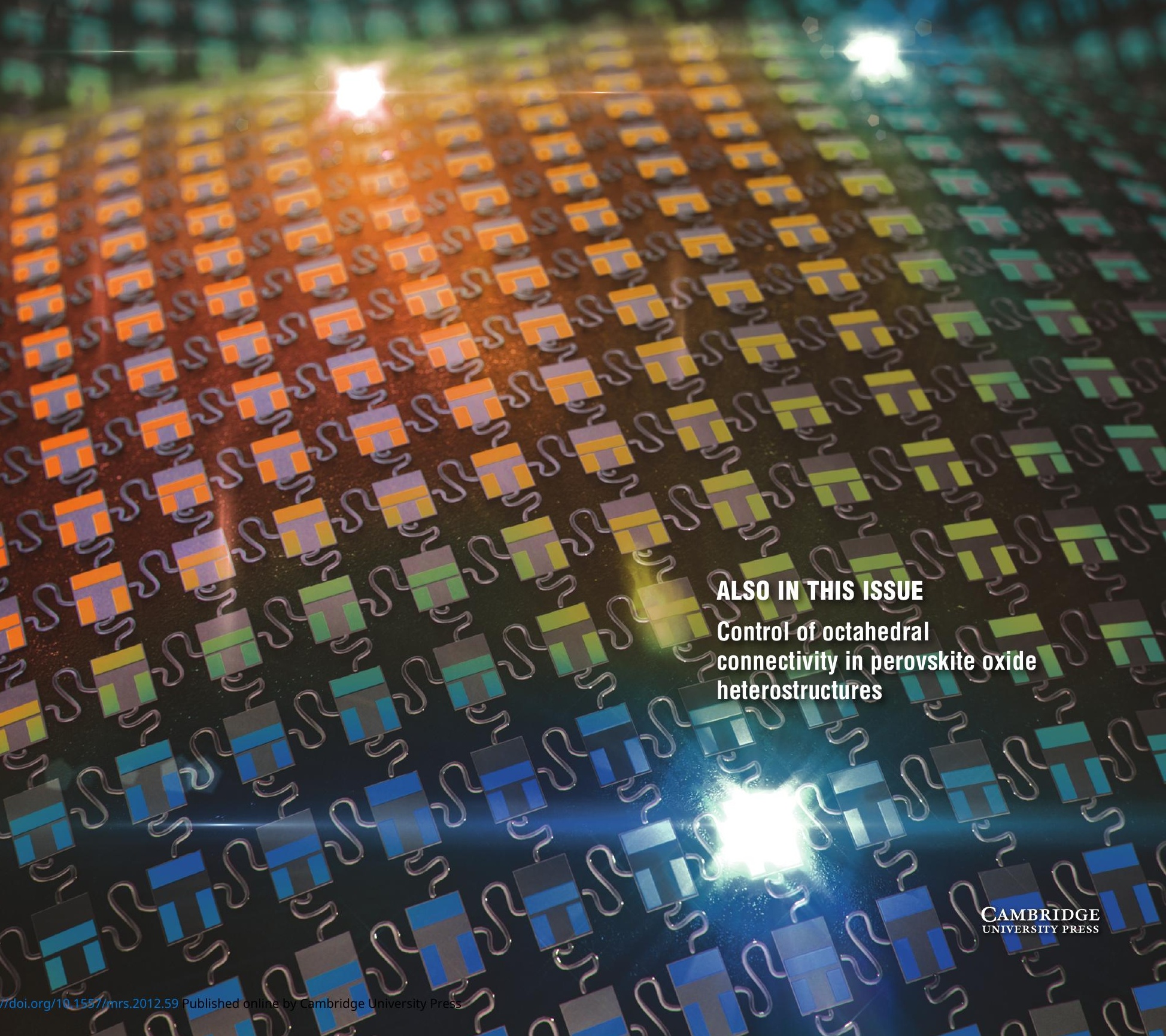




\section{CUSTOMIZED PRODUCTION ION IMPLANTERS}

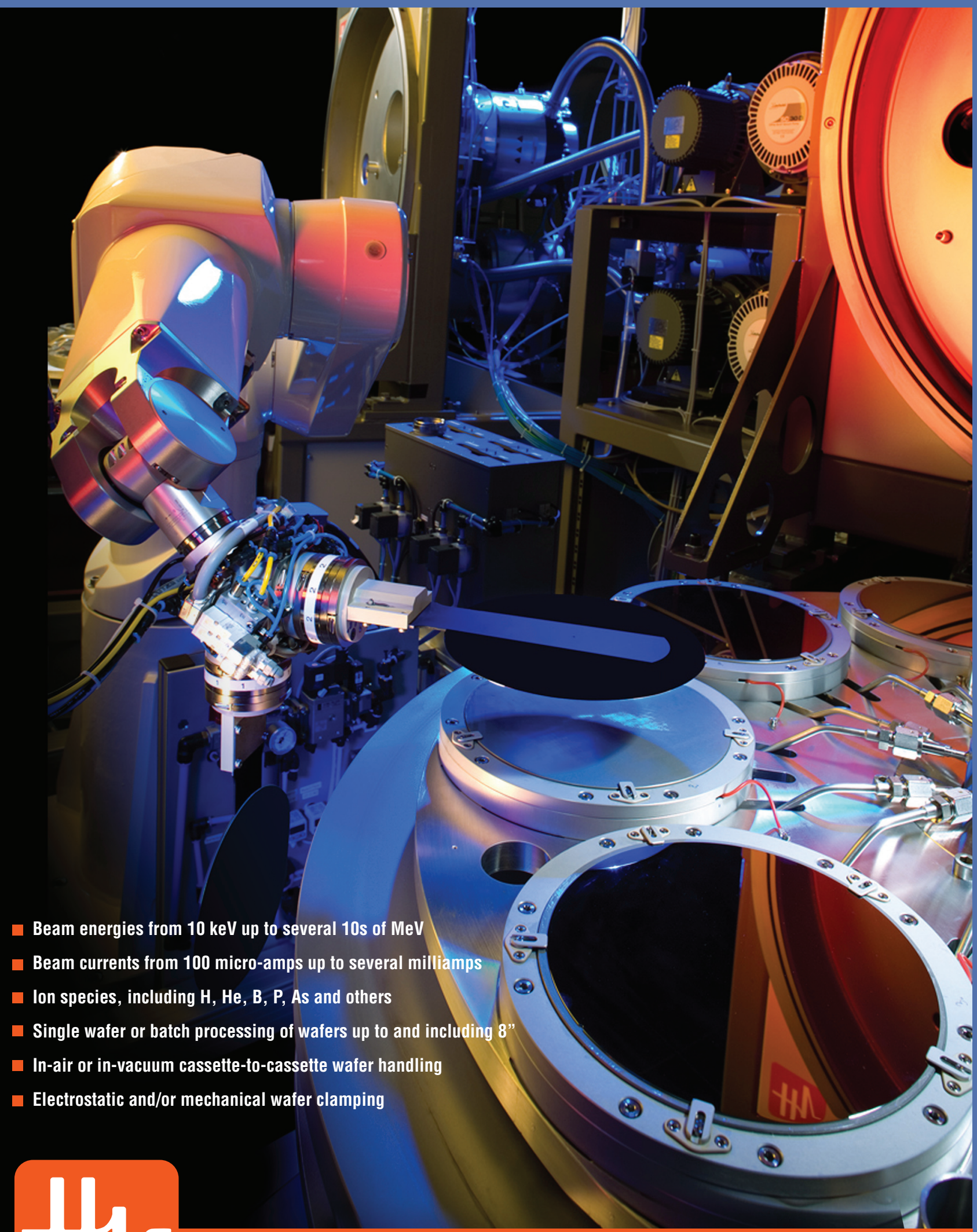

- Single wafer or batch processing of wafers up to and including 8 "

In-air or in-vacuum cassette-to-cassette wafer handling

Electrostatic and/or mechanical wafer clamping

\section{High Voltage Engineering}

High Voltage Engineering Europa B.V.

P.O. Box 99, 3800 AB Amersfoort, The Netherlands

Tel: $31334619741 \cdot$ info@highvolteng.com

www.highvolteng.com 


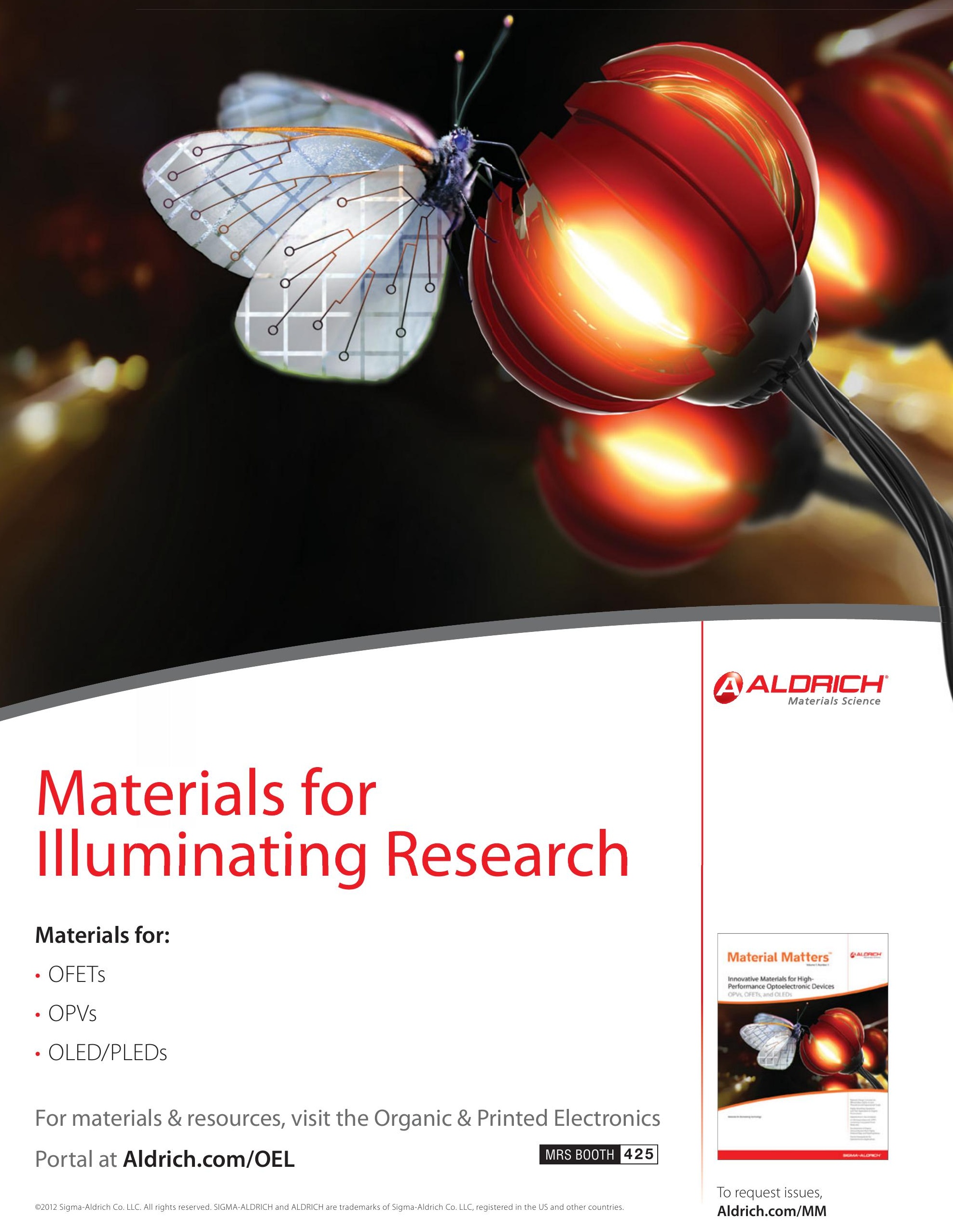




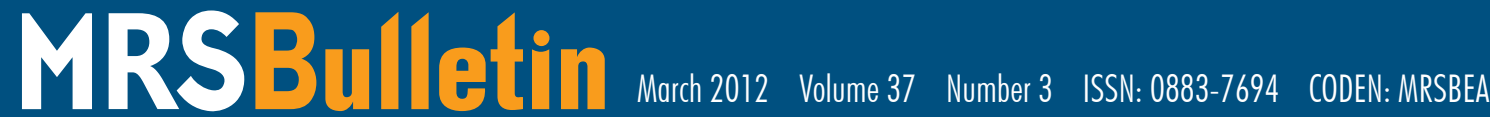
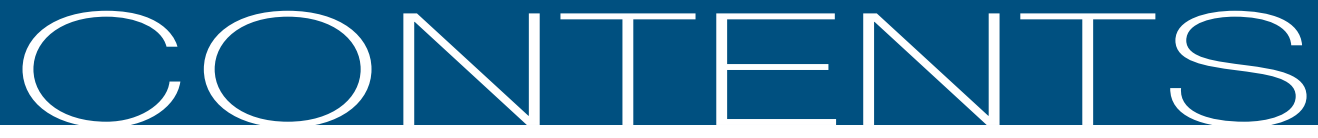

\section{MATERIALS FOR STRETCHABLE ELECTRONICS}

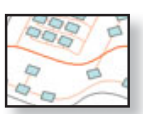

207 Materials for stretchable electronics Sigurd Wagner and Siegfried Bauer, Guest Editors

\section{Meet Our Authors}

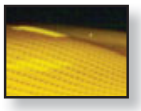

218 Mechanics of stretchable electronics and soft machines Zhigang Suo

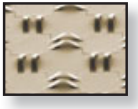

226 Materials for stretchable electronics in bioinspired and biointegrated devices Dae-Hyeong Kim, Nanshu Lu, Yonggang Huang, and John A. Rogers

236 Stretchable organic integrated circuits for large-area electronic skin surfaces Tsuyoshi Sekitani and Takao Someya

246 Dielectric elastomers: Stretching the capabilities of energy harvesting Roy D. Kornbluh, Ron Pelrine, Harsha Prahlad, Annjoe Wong-Foy, Brian McCoy, Susan Kim, Joseph Eckerle, and Tom Low

254 Printed circuit board technology inspired stretchable circuits

J. Vanfleteren, M. Gonzalez, F. Bossuyt, Y.-Y. Hsu, T. Vervust, I. De Wolf, and M. Jablonski

\section{TECHNICAL FEATURE}

261 Control of octahedral connectivity in perovskite oxide heterostructures: An emerging route to multifunctional materials discovery James M. Rondinelli, Steven J. May, and John W. Freeland

\section{Energy Quarterly}

193 Editorial

Materials fuel sustainable development

Marty Green

194 Energy Sector Analysis

Thinking small for solar

Corinna Wu

FEATURE EDITOR: Hideyuki Murata

196 Interview

The shift to advanced materials:

GM's Alan Taub surveys future

of the auto industry

Interviewed by David S. Ginley and Arthur L. Robinson

204 Regional Initiative

China and South Africa pursue

coal liquefaction

Prachi Patel

FEATURE EDITOR: Rocco Fiato

\section{Energy Focus}

Tim Palucka

Blog: www.materialsforenergy.org

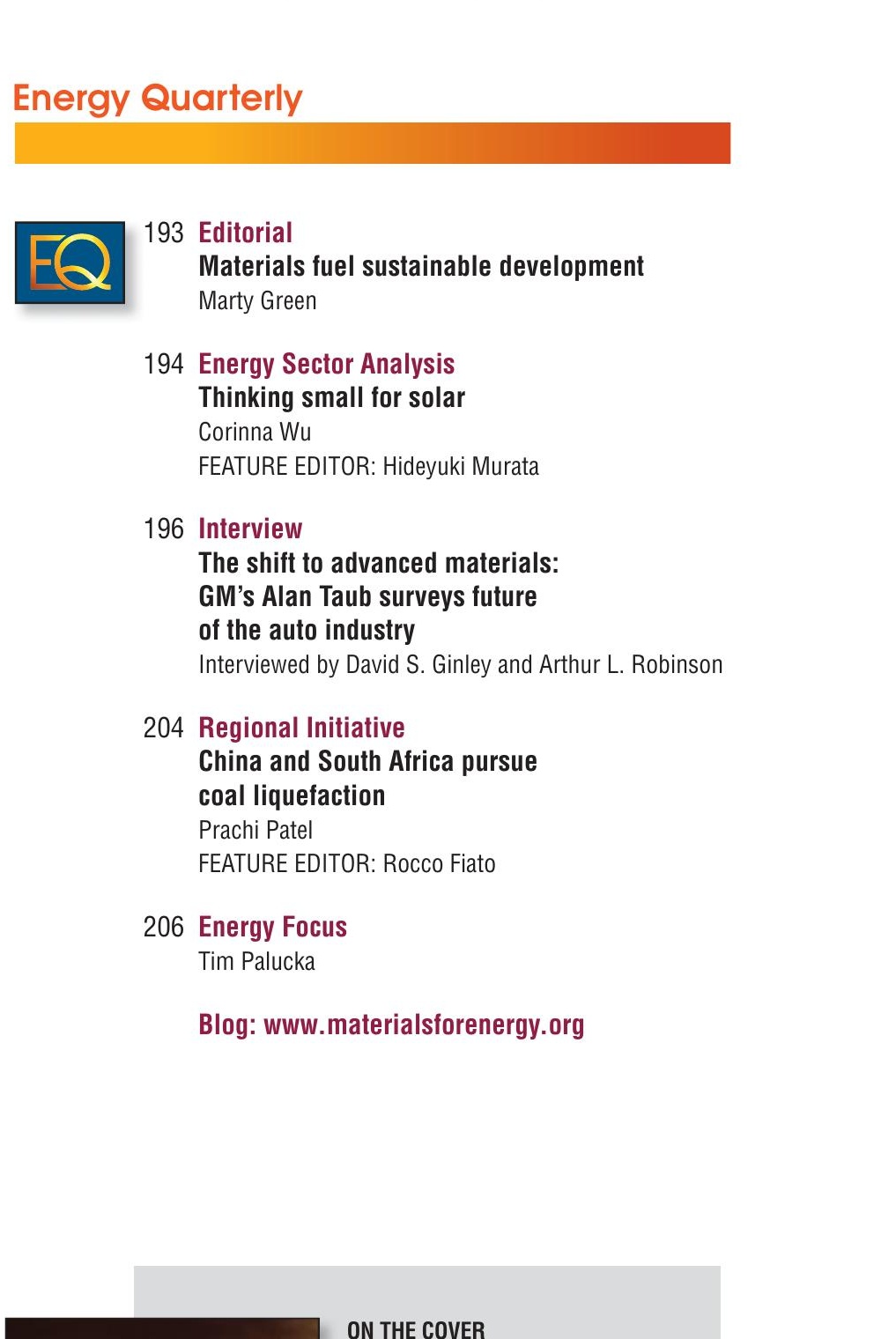

\section{ON THE COVER}

Materials for stretchable electronics. This issue of MRS Bulletin highlights stretchable electronics, the latest research frontier in large-area electronics. The cover shows an artistic rendering of electronic skin, conforming to irregularly curved surfaces and incorporating arrays of thin-film devices and integrated circuits. Electronic skin typically consists of diverse materials spanning more than 12 orders of magnitude in elastic modulus. The general architecture of an electronic skin is illustrated in the image, with a soft elastomeric substrate bearing stiff islands. The circuits on the islands include lightemitting diodes and are interconnected with elastic meander-shaped metallic conductors. The cover image is courtesy of Georg Wieser. See the technical theme that begins on page 207 . 


\section{DEPARTMENTS}

\section{NEWS \& ANALYSIS}

\section{Research/Researchers}

- Spider webs rely on nonlinear material behavior and architecture

Steven Trohalaki

- Molecular self-assembly controlled by different pathways

- Nanoscale transistor measures living cell voltages Tobias Lockwood

- Inverse spin Hall effect observed in silicon Steven Spurgeon

- Particle-free silver ink prints small, high-performance electronics

- Terahertz transmitter sets frequency record

191 Science Policy

- U.S. Congress to consider future of Federal Helium Reserve Kendra Redmond

- Reactor Institute Delft to receive funding

\section{SOCIETY NEWS}

- 2011 Materials Research Society Fall Meeting highlights state-of-the-art materials research

- Stephen J. Pennycook to receive MRS Innovation in Materials Characterization Award

- Kristi S. Anseth receives inaugural Mid-Career Researcher Award for biomaterials

- Markus J. Buehler named 2012 MRS Outstanding Young Investigator for computational modeling

- John Pendry to give plenary address on metamaterials at 2012 MRS Spring Meeting

- Thomas P. Russell to present Kavli lecture on nanoscience at 2012 MRS Spring Meeting

- Materials Research Society 2011 year-end review

\section{FEATURES}

\section{Books}

- Advanced batteries-Materials science aspects, Robert A. Huggins

Reviewed by Stan Whittingham

- Diffuse x-ray scattering and models of disorder T.R. Welberry

Reviewed by Richard Matyi

\section{Posterminaries}

It's elementary my dear Watson

Clif Draper

\section{ADVERTISERS IN THIS ISSUE} Page No.

* Advanced Research Systems .253

* Aldrich Materials Science........ 177

American Elements............................ Outside back cover

* Asylum Research. ...181

High Voltage Engineering ................... Inside front cover

* HORIBA Scientific.........................................................187

* International Centre

for Diffraction Data (ICDD) ....................................189

* Janis Research Company, Inc....................................217

* JEOL USA, Inc.............................................................. 183

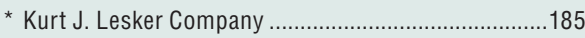

Lehigh Microscopy School.........................................217

* MMR Technologies, Inc. .........................................225

* National Electrostatics Corp........................................213

* Park Systems, Inc................................. Inside back cover

J.A. Woollam Company, Inc. ........................................190

*Please visit us at the Exhibit, April 10-12, during the 2012 MRS Spring Meeting in San Francisco.

\section{www.mrs.org/bulletin}

MRS members-access MRS Bulletin online

www.materialsforenergy.org

Join the conversation in the Materials for Energy blog

\section{www.mrs.org/mymrs}

MRS Publications Alert-

receive advance Table of Contents by email

http://journals.cambridge.org/

mrsbulletin-rss

Subscribe TODAY to the MRS Bulletin RSS Feed

\section{CAREER CENTRAL}




\section{About the Materials Research Society}

The Materials Research Society (MRS), a not-for-profit scientific association founded in 1973, promotes interdisciplinary goal-oriented basic research on materials of technological importance. Membership in the Society includes almost 16,000 scientists, engineers, and research managers from industrial, government, and university research laboratories in the United States and over 80 countries.

The Society's interdisciplinary approach differs from that of single-discipline professional societies because it promotes information exchange across the many technical fields touching materials development. MRS sponsors three major international annual meetings encompassing approximately 125 topical symposia, and also sponsors numerous single-topic scientific meetings. The Society recognizes professional and technical excellence and fosters technical interaction in local geographic regions through Sections and University Chapters.

MRS participates in the international arena of materials research through the International Union of Materials Research Societies (IUMRS). MRS is a member of the Alliance for Science \& Technology Research in America and is an affiliate of the American Institute of Physics.

MRS publishes The MRS Online Proceedings Library, MRS Bulletin, Journal of Materials Research, MRS Communications, and other publications related to current research activities.

\section{MRS BOARD OF DIRECTORS}

President Bruce M. Clemens, Stanford University, USA

Immediate Past President James J. De Yoreo, Lawrence Berkeley Nationa Laboratory, USA

Vice President and President-Elect Orlando Auciello, Argonne Nationa Laboratory, USA

Secretary Sean J. Hearne, Sandia National Laboratories, USA

Treasurer Michael R. Fitzsimmons, Los Alamos National Laboratory, USA

Executive Director Todd M. Osman, Materials Research Society, USA

Wade Adams, Rice University, USA

Ana Claudia Arias, University of California-Berkeley, USA

Shenda Baker, Synedgen, Inc./Harvey Mudd College, USA

Tia Benson Tolle, U.S. Air Force Research Laboratory, USA

Duane B. Dimos, Sandia National Laboratories, USA

Chang-Beom Eom, University of Wisconsin-Madison, USA

Eric Garfunkel, Rutgers University, USA

J. Murray Gibson, Argonne National Laboratory, USA

Oliver Kraft, Karlsruhe Institute of Technology, Germany

Hideki Matsumura, Japan Advanced Institute of Science and Technology, Japan

Ainissa Gweneth Ramirez, Yale University, USA

Stephen K. Streiffer, Argonne National Laboratory, USA

Susan E. Trolier-McKinstry, The Pennsylvania State University, USA

Pierre Wiltzius, University of California-Santa Barbara, USA

\section{MRS OPERATING COMMITTEE CHAIRS}

Academic Affairs M. Stanley Whittingham, SUNY-Binghamton, USA Awards Julia R. Weertman, Northwestern University, USA

Government Affairs Nabil Bassim, U.S. Naval Research Laboratory, USA

Meetings Committee David S. Ginley, National Renewable Energy

$$
\text { Laboratory, USA }
$$

Membership Yves Chabal, The University of Texas at Dallas, USA

Public Outreach Aditi Risbud, Lawrence Berkeley National Laboratory, USA

Publications Paul McIntyre, Stanford University, USA

MRS OFFICE OF PUBLIC AFFAIRS

Ron Kelley 499 South Capitol St. SW, Suite 600, Washington, DC 20003
Editor

Gopal R. Rao, rao@mrs.org

Managing Editor

Judy Meiksin, meiksin@mrs.org

Technical Editor

Lori A. Wilson, Iwilson@mrs.org

Editorial Assistants

Ben Moriarty, moriarty@mrs.org

Mary Wilmoth

Associate Technical Editor

Carol Tseng

Art Director

Kasia M. Bruniany

Production/Design

Andrea Pekelnicky, Christopher R. Roberts,

and TNQ

Production Editor

Catherine Paduani

Science News Editor

Tim Palucka

Principal Development Editor

Elizabeth L. Fleischer

Director of Communications

Eileen Kiley Novak
Guest Editors

Sigurd Wagner and Siegfried Baue

Special Contributors

B. Reeja Jayan and Rahul Reddy

Special Consultants

Babu Chalamala

Energy Quarterly

Steve M. Yalisove (Chair),

V.S. Arunachalam, Anshu Bharadwaj

David Cahen, Russell R. Chianelli,

George Crabtree, Abdelilah Slaoui,

Guillermo Solórzano,

and M. Stanley Whittingham

Advertising/Sponsorship

Mary E. Kaufold, kaufold@mrs.org

Donna L. Watterson, watterson@mrs.org

Member Subscriptions

Michelle Judt, judt@mrs.org

Non-Member Subscriptions

subscriptions_newyork@cambridge.org

\section{EDITORIAL BOARD}

Paul S. Drzaic (Chair), Apple, Inc., USA

V.S. Arunachalam, Center for Study of Science, Technology \& Policy, India

Marie-Isabelle Baraton, University of Limoges, France

Robert C. Cammarata, Johns Hopkins University, USA

Laura Fornaro, University of Uruguay, Uruguay

Hanns-Ulrich Habermeier, Max Planck Institute for Solid State Research, Germany

Fiona C. Meldrum, University of Leeds, UK

Amit Misra, Los Alamos National Laboratory, USA

Julie A. Nucci, Cornell University, USA

Linda J. Olafsen, Baylor University, USA

David N. Seidman, Northwestern University, USA

Carol Trager-Cowan, University of Strathclyde, UK

Julia R. Weertman, Northwestern University, USA

Eric Werwa, Washington, DC, USA

Steve M. Yalisove, University of Michigan, USA

\section{VOLUME ORGANIZERS}

2013 Mark T. Lusk, Colorado School of Mines, USA Eva Olsson, Chalmers University of Technology, Sweden Birgit Schwenzer, Pacific Northwest National Laboratory, USA James W. Stasiak, Hewlett-Packard Co., USA

2012 Lei Jiang, Chinese Academy of Sciences, China Sergei V. Kalinin, Oak Ridge National Laboratory, USA Stéphanie P. Lacour, EPFL, Switzerland Steven C. Moss, Aerospace Corporation, USA

2011 Kyoung-Shin Choi, Purdue University, USA Reuben T. Collins, Colorado School of Mines, USA Sean E. Shaheen, University of Denver, USA

MRS Bulletin (ISSN: 0883-7694, print; ISSN 1938-1425, online) is published 12 times a year by the Materials Research Society, 506 Keystone Drive, Warrendale, PA 15086-7573. Copyright $\odot$ 2012, Materials Research Society. Permission required to reproduce content. Periodical postage paid at New York, NY, and at additional mailing offices. POSTMASTER: Sen address changes to MRS Bulletin in care of the Journals Department, Cambridge University Press, 100 Brook Hill Drive, West Nyack, NY 10994-2113, USA. Printed in the U.S.A.

Membership in MRS is $\$ 115$ annually for regular members, $\$ 30$ for students. Dues include an allocation of $\$ 29$ ( $\$ 17$ for students) to a subscription to MRS Bulletin. Individual member subscriptions are for personal use only. Non-member subscription rates are $\$ 363$ for one calendar year (12 issues) within North America and $\$ 436$ elsewhere. Requests from subscribers for missing journal issues will be honored without charge only if received within six months of the issue's actual date of publication.

MRS Bulletin is included in Current Contents $\circledast$ /Engineering, Computing, and Technology; Current Contents $\circledast /$ Physical, Chemical, and Earth Sciences, the SciSearch $\circledast$ online data-

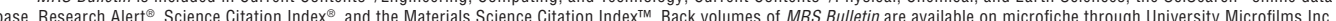
300 North Zeeb Road, Ann Arbor, MI 48106, USA. 
